\title{
Seroepidemiology of Peste Des Petits Ruminants (PPR) in Sheep and Goats of Southern Districts of Gujarat, India
}

\author{
Pramod Sakhare $^{1 *}$, Irshadullahkhan Kalyani ${ }^{1}$, Priti Vihol ${ }^{2}$, Kishan Sharma ${ }^{1}$, \\ Jayesh Solanki ${ }^{3}$, Dhruv Desai ${ }^{1}$ and Pushpa Makwana ${ }^{1}$
}

\author{
${ }^{1}$ Department of Veterinary Microbiology, ${ }^{2}$ Department of Veterinary Pathology \\ ${ }^{3}$ Department of Veterinary Parasitology, College of Veterinary Science and Animal \\ Husbandry, Navsari Agriculture University, Navsari, Gujarat, India
}

*Corresponding author

\section{A B S T R A C T}

\begin{tabular}{|c|}
\hline Keywords \\
\hline $\begin{array}{l}\text { PPR, Gujarat, } \\
\text { Sheep, Goats, } \\
\text { PPRV antibodies, } \\
\text { Seroprevalence, c- } \\
\text { ELISA }\end{array}$ \\
\hline Article Info \\
\hline $\begin{array}{l}\text { Accepted: } \\
12 \text { October } 2019 \\
\text { Available Online: } \\
10 \text { November } 2019\end{array}$ \\
\hline
\end{tabular}

\section{Keywords}

PPR, Gujarat,

Sheep, Goats

PPRV antibodies,

Seroprevalence, c-

ELISA

Article Info

12 October 2019

10 November 2019
A total of 750 serum samples from sheep and goats of Navsari, Valsad, Surat and Tapi districts of south Gujarat were screened for PPR specific antibodies using PPR competitive ELISA (c-ELISA). The Overall seroprevalence of PPR was found $62.40 \%$ (468/750).Based on affected species, seropositivity was noted significantly higher in goats $65.77 \%$ than sheep $43.96 \%$.Among the districts, Surat topped the list $(66.46 \%)$ followed by Valsad (62.67\%), Tapi $(60.76 \%)$ and Navsari $(60.24 \%)$.Higher seroprevalence rate $(66.25 \%)$ was found males in comparison to their female counterparts (61.35\%). Age wise higher seroprevalence $(66.23 \%)$ was recorded among the age group of 1 to 3 years, followed by $<1$ year age group $(58.58 \%)$ and with least seroprevalence in $>3$ years of age group $(10.75 \%)$. In case of goats, maximum seroprevalence was recorded in Valsad district $(67.34 \%)$ whereas least seroprevalence was recorded in Navsari (63.94\%). Seropositivity was higher in male $(69.71 \%)$ than the female $(64.63 \%)$. The age group of 1 to 3 years was highest seropositive (70.63\%) than above 3 years of age (27.77\%). Among sheep, district wise seroprevalence of PPR was noted to be highest in Valsad (51.61\%) and lowest in Tapi $(27.77 \%)$. In female sheep, the seropositivity was noted higher having $44.89 \%$ cases however; males exhibited a lower (38.88\%). The highest rate of seroprevalence (45.67\%) was observed in the age group of 1 to 3 years than $(40.00 \%)$ recorded in remaining age groups. Month wise overall seropositivity found highest in October $(72.88 \%)$ followed by December $(63.86 \%)$.

\section{Introduction}

PPR is a highly contagious, acute, febrile viral disease in goats and sheep, characterized by fever, anorexia, depression, nasal discharge, ocular discharge, anorexia, abortion, erosion on nasal mocosa, stomatitis, coughing and depression (Tariq et al., 2014). Therefore, World Organization of Animal Health (WOAH) has identified PPR as a 
notifiable and economically important transboundary viral disease of sheep and goats (Balamurgan et al., 2010). Peste des petits ruminants virus (PPRV) infect sheep and goats, although both cattle and pigs are susceptible to infection, but do not contribute to the epidemiology as they are unable to excrete virus (Kahn, 2010). The PPRV is a RNA virus belonging to the genus Morbillivirus and family Paramyxoviridae. The virus is closely related to rinderpest virus (Anderson et al., 1990; Couacy-Hymann et al., 1995) measles and canine distemper (Gibbs et al., 1979).

In India, the disease has great economic importance on basis of mortality, morbidity, losses through body wastage, poor food efficiency, loss of the meat, milk and milk products, wool losses and also offspring. The percentage of the livestock derived income loss due to PPR varies between 21-90\% (FAO, 2009). The morbidity $(65.66 \%)$ and mortality (34.34\%) contribute mainly in overall losses due to PPR outbreaks and prevalence in India(Singh et al., 2014).PPR was first reported from Tamil Nadu in 1987 (Shaila et al., 1989). For many years the disease was supposed to be confined in the southern parts of the country (Krishna et al., 2001). However, during 1994, a major epidemic of PPR spread across the country, the disease has been recorded from northern states as well as West Bengal (Dhar et al., 2002). Within a decade, PPR became endemic in the country, imposing severe threat to small ruminant industry.

At present, regularly outbreaks occur among small ruminants throughout the country (Kerur et al., 2008) and the overall prevalence of PPRV was reported within the range of 20$60 \%$ (Singh et al., 2004a). Many reports documented the presence of PPRV in Rajasthan in the north (Kataria et al., 2007), Kolkataregion in the east (Saha et al., 2005),
Karnataka in the south and Maharashtra in the west (Santosh et al., 2009; Raghayendra et al., 2008). No epidemic of PPR had been reported in Gujarat till 2014. But, presence of PPRV was studied and confirmed from Gujarat in 2001 (Hinshu et al., 2001) and later on by other workers (Tiwari et al., 2004; Nagraj, 2006; Kanani et al., 2006; Chandrahas, et al., 2011; Sharma et al., 2015)

PPR is characterized by pyrexia, ocular and nasal discharges, erosive and necrotic stomatitis, conjunctivitis, gastroenteritis, diarrhoea and pneumonia. PPR is primarily a disease of goats and sheep, however, goats are usually more severely affected than sheep (Lefevre et al., 1990; OIE, 2013). The virus is shed in all body secretions and excretions, thus transmission of PPR requires close contact between susceptible and infected animals and occurs mainly through inhalation of aerosols produced by sneezing and coughing. The disease usually appears after an introduction of new animals into a herd. Fomites such as bedding may also contribute to the onset of an outbreak (Lefevre et al., 1990).

The distribution and prevalence of PPR may be diagnose and monitor by epidemiological case recording of PPR outbreaks, serological detection of PPR specific antibodies and detection of the virus. The most commonly used method is c-ELISA for serological diagnosis of PPR due to its highly sensitivity (94.5\%) and specificity (99.4\%) compared to virus neutralization assay that can detect PPRV antibodies in the sera of affected sheep and goats after the first week of infection (Libeau et al., 1995; Singh et al., 2004b) however, it is not useful method as it does not differentiate vaccinated from infected animals. Hence, Present study was undertaken to find out the age wise, sex wise, species wise and season wise prevalence of the disease based on the diagnostic modality. 
Materials and Methods

\section{Study area}

During 2015 to 2017, suspected PPR outbreaks among sheep and goats occurred in different locations namely: Navsari, Valsad, Surat and Tapi districts of south Gujarat (Fig. $1)$.

In the present study, a total of 750 (goats: 634 and sheep: 116) serum samples from sheep and goats of same area were screened for PPR specific antibodies using PPR c-ELISA.

Collection and preparation of serum samples

About $5 \mathrm{ml}$ of blood was collected aseptically from the jugular vein of each animal in a vacuette with serum clot activator (Greiner bio-one, Austria). The vacuettes were kept in upright position at room temperature for about two hours.

The separated serum was collected in a screw capped plastic vials and transported to the laboratory. The sera were stored at $-20^{\circ} \mathrm{C} /-80$ ${ }^{\circ} \mathrm{C}$ temperatures till further use.

All the serum samples were collected from 750 animals (goats: 634 and sheep: 116) under the present study described in Table 1 and 2 .

In order to confirm that PPRV was the main cause of the recent suspected outbreaks, Nasal, conjunctival and oral swabs were collected by rubbing cotton swabs against mucosal surfaces, suspended in VTM which was kept in icepacking and quickly transported to the laboratory as quickly as possible.

Tissues were collected from died animals and quickly transported to laboratory on ice and stored at $-80^{\circ} \mathrm{C}$. Sera were collected from both infected and healthy animals in the herds. All the serum samples were analyzed by c-ELISA.

\section{Competitive Enzyme Linked Immunosorbent Assay (c-ELISA)}

For detection of PPRV antibodies in the collected sera, c-ELISA using monoclonal antibodies directed against PPRV nucleoprotein gene was performed using commercial ELISA kit, ID Screen ${ }^{\circledR} \mathrm{PPR}$ Competition kit (IDVet Innovative Diagnostics, France) following the manufacturer's instructions.

\section{Statistical analysis}

The statistical analysis of data generated on various parameters was carried out by Standard Statistical procedures using Statistical Packages for Social Science (SPSS) software (version 17). Chi-square test was used according to WEB AGRI STAT PACKAGE software developed by Ashok Kumar, ICAR research complex, Goa, India.

\section{Results and Discussion}

Suspected PPR outbreak serum samples were tested for the period of 2015 to 2017. Detailed overall seroprevalence described in table 3 . Different attributes were also calculated and presented in table 4 .

\section{Description of PPR clinical disease in sheep and goats}

Sheep and goats from PPR suspected outbreaks were recognized mostly by the appearance of the typical clinical signs of the disease including pyrexia, anorexia, profuse serous nasal and ocular discharges while some animals showed mucopurulent discharges, dry muzzle, respiratory signs and diarrhea. The cases were associated with a higher morbidity and mortality rates particularly among young animals. No any vaccinations against PPR in sheep and goats herds in these areas were carried out declared by animal owners. 


\section{Detection of PPRV antibodies using c- ELISA}

Examination of 750 sera samples i.e. 634 goats and 116 sheep sera by c-ELISA for the presence of PPRV antibodies indicated that468 $(62.40 \%)$ sera were found positive for PPR antibodies. This was combined/ overall seroprevalence of PPR in the goats and sheep of the four districts of south Gujarat under the study.

\section{District wise seroprevalence}

District wise seroprevalence in Navsari, Valsad, Surat and Tapi districts was found as $60.24,62.67,66.46$ and 60.76 per cent, respectively. Seroprevalence was found higher in Surat whereas almost equal percent positivity was observed from Valsad, Tapi and Navsari districts. Among goats, highest Prevalence was recorded in Valsad $(67.34 \%)$ followed by Surat (66.46\%), Tapi $(66.07 \%)$ and Navsari (63.94\%) district. While the decreasing order for sheep was Valsad (51.61\%), Navsari (38.88\%) and Surat (27.77\%), and Tapi (0.0\%) (Fig. 2).

Species wise seroprevalence of PPRV antibodies

On the basis of affected species, seropositivity was noted as $65.77 \%(417 / 634)$ in goats and $43.96 \%(51 / 116)$ in sheep which showed extremely statistically significant $(\mathrm{P}<0.0001)$ variation between species towards susceptibility of PPRV infection (Fig. 3).

\section{Sexwise seroprevalence}

The sex wise overall seroprevalence of PPR disease was reported higher $66.25 \%$ (106/160) in male than that to females i.e. $61.35 \%$ (362/590). Male goats showed numerically higher seroprevalence $(69.71 \%)$ as compared to females $(64.63 \%)$. The situation among sheep was reverse and the female sheep showed higher seroprevalence $(44.89 \%)$ than that of males $(38.88 \%)$.

\section{Age wise seroprevalence}

Age wise overall seroprevalence was observed significantly $(\mathrm{P}<0.01)$ higher in 1 to 3 years of age which is $66.23(304 / 459)$ followed by less than 1 year of age group as 58.58 (157/268) per cent. While $30.43 \%(7 / 23)$ seropositivity was found in $>3$ years of age group. In respect of age, maximum seroprevalence (70.63\%) was found in goat of 1-3 years of age followed by the age group of $<1$ year $(60.92 \%)$ and $>3$ years $(27.77 \%)$. When sheep sera were tested as per same age grouping maximum seroprevalence $(45.67 \%$ ) was found in animals above 1-3 years of age, than the age group of $<1$ year $(40 \%)$ and $>3$ years $(40 \%)$. Unlike goat, the age wise prevalence was not differing significantly among groups.

\section{Month wise seroprevalence}

Highest overall and within the species month wise positivity was noted in October followed by December (Fig. 4). Total two seasons and over the six month study revealed difference in outbreak of disease and percent positivity. Fall and spring season are the most critical period of the disease occurrence. The detailed were presented in table 4. Disease occurrence duration in our study can be draw from the frequency distribution (Figure 5) which clearly depicted that the duration time of September to January is the most susceptible for the PPR infection in small ruminants.

Our finding are corroborates with the reports (Chauhan et al., 2011) where 112/176 $(63.64 \%)$ sera samples were positive for PPRV antibodies in migratory/ village flocks of sheep and goats of Kutchh region of Gujarat state. Again (Chauhan et al., 2012) studied seroepidemiology and found $51.86 \%$ 
(503/970) seroprevalence of PPR in sheep and goats maintained under different managemental conditions.

Lesser than our results, seropositivity level at $33.33 \%$ in south Gujarat (Tiwari, 2004) and $37.09 \%$ in Gujarat state (Ranaware et al., 2013) was recorded. Similarly, $25.70 \%$ (Thakor et al., 2016) and $47.14 \%$ recorded an overall seroprevalence in case of goats of south Gujarat (Patel et al., 2017). The overall $46.26 \%$ seroprevalence of PPRV infection in sheep and goats of North Gujarat was reported (Chandrahas et al., 2011)and found 43.56 per cent of overall prevalence in different states of India between 2003 and 2009 year period (Balamurugan et al., 2011). The overall seroprevalence $47.5(114 / 240)$ and 35.23 (2500/7096) per cent were observed in southern part of Tigray region of Ethiopia (Afera et al., 2014) and Sindh province of Pakistan (Nizamani et al., 2015), respectively.

Among districts, Percent positivity of Navsari district was in accordance with (Patel et al., 2017) but higher than (Thakor et al., 2016). Higher prevalence of PPR in Valsad district of south Gujarat was reported earlier (Thakor et al., 2016). The Surat district was not included in the earlier studies by any worker. In Pakistan, there were found 43.33 per cent seroprevalence was noted in 24 districts of Punjab Province (Khan et al., 2007) and $45.5 \%$ from different villages of 27 randomly selected districts.

In species wise study, we found significant difference $(\mathrm{P}<0.01)$. Seroprevalence in goat was found as $65.77 \%(417 / 634)$ which is higher than sheep $43.96 \%$ (51/116). The results have been concurred with the findings of earlier workers (Tiwari et al., 2004; Wang et al., 2009; Balamurugan et al., 2011; Rahman et al., 2017). In general goats are more susceptible than sheep, therefore have a higher probability of developing PPRV antibodies (Kumar et al., 2014). However, reports from India (Chandrahas et al., 2011) and from Pakistan (Khan et al., 2007; Nizamani et al., 2015) have been showed higher seroprevalence in sheep than goats. Non-significant difference was observed in seroprevalence for both of species.

The sex-wise overall seroprevalence of PPR disease was reported higher $66.25 \%$ (106/160) in male than that to females i.e. $61.35 \%$ (362/590). Although the differences observed in PPR seroprevalence between males and females was statistically non significant. This is in agreement with (Thakor et al., 2016) who observed non significant difference on sex wise basis in south Gujarat. The prevalence values reported here are in concordance with report of Maharasthra, India (Karelewad et al., 2007)who recorded sex-wise prevalence was higher in male $(73.28 \%)$ as compared to female $(55.22 \%)$ goats in and similarly report (Mahajan et al., 2012), found significantly higher seroprevalence in males $(33.33 \%)$ than the females $(24.53 \%)$ in $\mathrm{J} \& \mathrm{~K}$, India.

Higher seroprevalence of PPR in female than male in south Gujarat was observed earlier (Patel et al., 2017). On the contrary, we found higher seroprevalence in male because the outbreaks were observed during the festive season during which demands for male was more. Similarly, many of the workers found higher prevalence in does than bucks (Mahajan et al., 2012; Nizamani et al., 2015; Rahman et al., 2017; Patel et al., 2017).

Largely, per cent variation might be due to difference in sample size in these two cases. For sheep most of studies have shown a higher prevalence in female population (Khan et al., 2007; Nizamani et al., 2015) which support our present findings. Similar trends of the results have been found by previous worker on sex wise basis (Thakor et al., 2016). 
Age-wise overall seroprevalence was observed significantly $(\mathrm{P}<0.01)$ higher in 1 to 3 years followed by less than 1 year of age group as $66.23(304 / 459)$ and $58.58(157 / 268)$ per cent, respectively. While, only $30.43 \%$ (7/23) sero positivity was found in age $>3$ years. These findings are in agreement with previous reports from Gujarat (Chauhan et al., 2012)and J\& K, India (Mahajan et al., 2012).
The former recorded Maximum seroprevalence of 55.65 per cent was found in the age group of $>3$ years, followed by 2 to 3 years $(52.00 \%), 1$ to 2 years $(31.91 \%)$ and < 1 year $(27.87 \%)$ in goats, and later author noted significantly $(\mathrm{p}<0.05)$ higher seroprevalence in $>12$ months age group (39.58\%) followed by $8-12$ months (26.38\%) and 4-8 months (20.83\%) age group.

Table.1 Details of districts, species, age and sex wise serum samples collection in goat and sheep

\begin{tabular}{|c|c|c|c|c|c|c|c|}
\hline \multirow[t]{2}{*}{ Species } & \multirow[t]{2}{*}{ Age groups } & \multirow[t]{2}{*}{ Sex } & \multicolumn{4}{|c|}{ Districts } & \multirow[t]{2}{*}{ Total } \\
\hline & & & Navsari & Valsad & Surat & Tapi & \\
\hline \multirow[t]{6}{*}{ Goat } & \multirow[t]{2}{*}{$<1$ year } & Male & 51 & 31 & 36 & 30 & 148 \\
\hline & & Female & 54 & 42 & 54 & 36 & 186 \\
\hline & \multirow[t]{2}{*}{$1-3$ years } & Male & 4 & 34 & 2 & 3 & 43 \\
\hline & & Female & 38 & 5 & 43 & 30 & 116 \\
\hline & \multirow[t]{2}{*}{ Above 3 years } & Male & 5 & 4 & 2 & 1 & 12 \\
\hline & & Female & 56 & 31 & 30 & 12 & 129 \\
\hline \multicolumn{3}{|c|}{ Total } & 208 & 147 & 167 & 112 & 634 \\
\hline \multirow[t]{6}{*}{ Sheep } & \multirow[t]{2}{*}{$<1$ year } & Male & 4 & 8 & -- & -- & 12 \\
\hline & & Female & 7 & 10 & -- & -- & 17 \\
\hline & \multirow[t]{2}{*}{$1-3$ years } & Male & 2 & 3 & -- & 1 & 6 \\
\hline & & Female & 16 & 34 & -- & 14 & 64 \\
\hline & \multirow[t]{2}{*}{ Above 3years } & Male & 0 & 0 & -- & -- & -- \\
\hline & & Female & 7 & 7 & & 3 & 17 \\
\hline \multicolumn{3}{|c|}{ Total } & 36 & 62 & -- & 18 & 116 \\
\hline \multicolumn{3}{|c|}{ Overall } & 244 & 209 & 167 & 130 & 750 \\
\hline
\end{tabular}

Table.2 Details of month wise sample collection from sheep and goat

\begin{tabular}{|c|c|c|c|}
\hline Particular & \multicolumn{3}{|c|}{ No. of samples } \\
\hline & Goat & Sheep & Total \\
\hline & Month wise & & \\
\hline August & 82 & -- & 82 \\
\hline September & 81 & 18 & 99 \\
\hline October & 163 & 14 & 177 \\
\hline December & 205 & 69 & 274 \\
\hline January & 56 & 15 & 71 \\
\hline February & 47 & -- & 47 \\
\hline Total & $\mathbf{6 3 4}$ & $\mathbf{1 1 6}$ & $\mathbf{7 5 0}$ \\
\hline
\end{tabular}


Table.3 Overall seroprevalence of PPR diagnosed by c-ELISA

\begin{tabular}{|c|c|c|c|}
\hline Attributes & No. of Tested & No. of Positive & Percent Positive \\
\hline \multicolumn{4}{|c|}{ Region } \\
\hline South Gujarat & 750 & 468 & 62.40 \\
\hline \multicolumn{4}{|c|}{ Species } \\
\hline Goat & 634 & 417 & 65.77 \\
\hline Sheep & 116 & 51 & 43.96 \\
\hline Total & 750 & 468 & 62.40 \\
\hline$\chi^{2}=19.876^{* *}(\mathrm{P}<0.0001)$ & & & \\
\hline \multicolumn{4}{|l|}{$\pi$} \\
\hline Male & 160 & 106 & 66.25 \\
\hline Female & 590 & 362 & 61.35 \\
\hline Total & 750 & 468 & 62.40 \\
\hline \multicolumn{4}{|l|}{$\chi^{2}=1.285(\mathrm{P}>0.05)$} \\
\hline \multicolumn{4}{|l|}{ Age } \\
\hline$<1$ year & 268 & 157 & 58.58 \\
\hline $1-3$ years & 459 & 304 & 66.23 \\
\hline$>3$ years & 23 & 07 & 30.43 \\
\hline Total & 750 & 468 & 62.40 \\
\hline$\chi^{2}=14.552 * *(\mathrm{P} \leq 0.001)$ & & & \\
\hline
\end{tabular}

Fig.1 showing four districts namely Navsari, Valsad, Surat and Tapi were selected for study

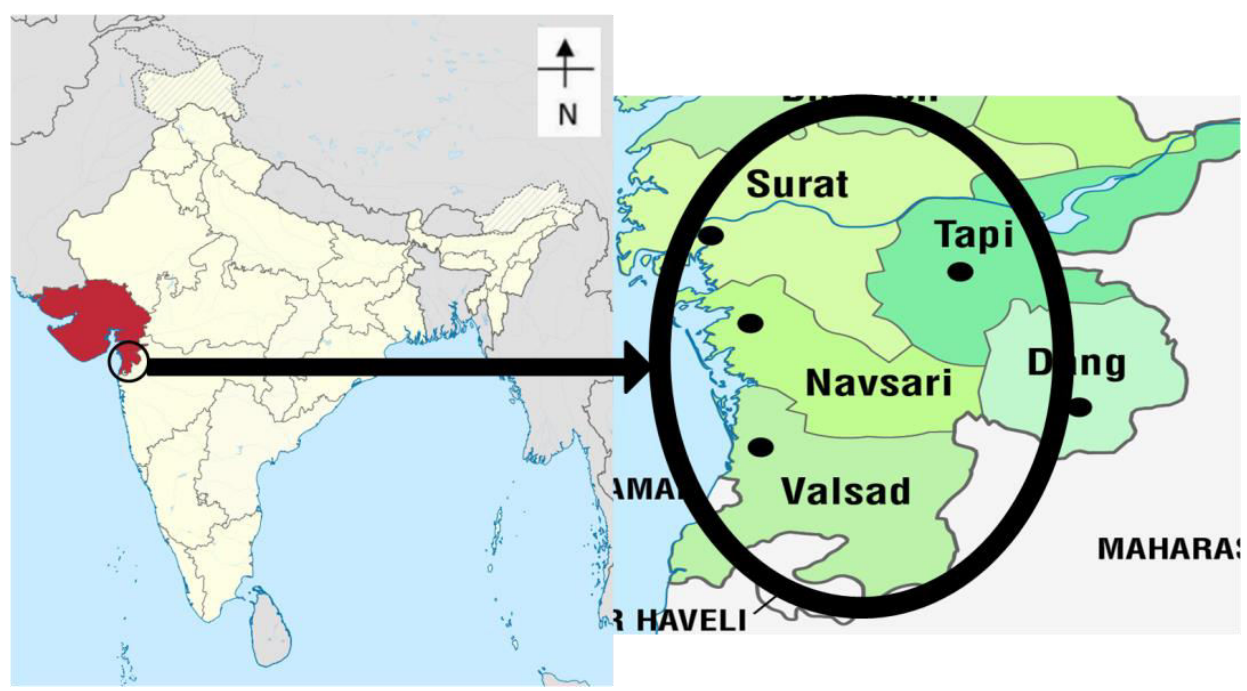


Table.4 Correlation of region, districts, sex and age between the Goat and Sheep of PPR seroprevalence

\begin{tabular}{|c|c|c|c|c|c|c|}
\hline \multirow[t]{2}{*}{ Attributes } & \multicolumn{3}{|c|}{ Goat } & \multicolumn{3}{|c|}{ Sheep } \\
\hline & $\begin{array}{l}\text { No. of } \\
\text { Tested }\end{array}$ & $\begin{array}{l}\text { No. of } \\
\text { Positive }\end{array}$ & $\begin{array}{l}\text { Percent } \\
\text { Positive }\end{array}$ & $\begin{array}{l}\text { No. of } \\
\text { Tested }\end{array}$ & $\begin{array}{l}\text { No. of } \\
\text { Positive }\end{array}$ & $\begin{array}{l}\text { Percent } \\
\text { Positive }\end{array}$ \\
\hline \multicolumn{7}{|c|}{ Region } \\
\hline SouthGujarat & 634 & 417 & 65.77 & 116 & 51 & 43.96 \\
\hline \multicolumn{7}{|c|}{ Districts } \\
\hline Valsad & 147 & 99 & 67.34 & 62 & 32 & 51.61 \\
\hline Navsari & 208 & 133 & 63.94 & 36 & 14 & 38.88 \\
\hline Tapi & 112 & 74 & 66.07 & 18 & 5 & 27.77 \\
\hline Surat & 167 & 111 & 66.46 & -- & -- & -- \\
\hline \multirow[t]{2}{*}{ Total } & 634 & 417 & 65.77 & 116 & 51 & 43.96 \\
\hline & \multicolumn{2}{|c|}{$\chi^{2}=0.512(P>0.05)$} & & \multicolumn{2}{|c|}{$\chi^{2}=3.763(\mathrm{P}>0.05)$} & \\
\hline \multicolumn{4}{|c|}{ Sex } & & & \\
\hline Male & 142 & 99 & 69.71 & 18 & 7 & 38.88 \\
\hline Female & 492 & 318 & 64.63 & 98 & 44 & 44.89 \\
\hline \multirow[t]{2}{*}{ Total } & 634 & 417 & 65.77 & 116 & 51 & 43.96 \\
\hline & \multicolumn{2}{|c|}{$\chi^{2}=0.512 \quad(\mathrm{P}>0.05)$} & & \multicolumn{2}{|c|}{$\chi^{2}=0.223(\mathrm{P}>0.05)$} & \\
\hline \multicolumn{4}{|c|}{ Age } & & & \\
\hline$<1$ year & 238 & 145 & 60.92 & 30 & 12 & 40.00 \\
\hline $1-3$ years & 378 & 267 & 70.63 & 81 & 37 & 45.67 \\
\hline$>3$ years & 18 & 05 & 27.77 & 5 & 2 & 40.00 \\
\hline \multirow[t]{2}{*}{ Total } & 634 & 417 & 65.77 & 116 & 51 & 43.96 \\
\hline & \multicolumn{2}{|c|}{$\begin{array}{c}\chi^{2}= \\
14.552 * *(\mathrm{P} \leq 0.001)\end{array}$} & & \multicolumn{2}{|c|}{$\chi^{2}=0.32(\mathrm{P}>0.05)$} & \\
\hline \multicolumn{7}{|c|}{ Month } \\
\hline August & 82 & 42 & 51.21 & -- & -- & -- \\
\hline September & 81 & 45 & 55.55 & 18 & 7 & 38.88 \\
\hline October & 163 & 121 & 74.23 & 14 & 8 & 57.14 \\
\hline December & 205 & 144 & 70.24 & 69 & 31 & 44.92 \\
\hline January & 56 & 36 & 64.20 & 15 & 5 & 33.33 \\
\hline February & 47 & 29 & 61.70 & -- & -- & -- \\
\hline \multirow[t]{2}{*}{ Total } & 634 & 417 & 65.77 & 116 & 51 & 43.96 \\
\hline & \multicolumn{2}{|c|}{$\begin{array}{c}\chi^{2}= \\
18.334^{* * *}(\mathrm{P}<0.01)\end{array}$} & & \multicolumn{2}{|c|}{$\chi^{2}=1.889(\mathrm{P}>0.05)$} & \\
\hline
\end{tabular}


Fig.2 District wise seroprevalence of PPR

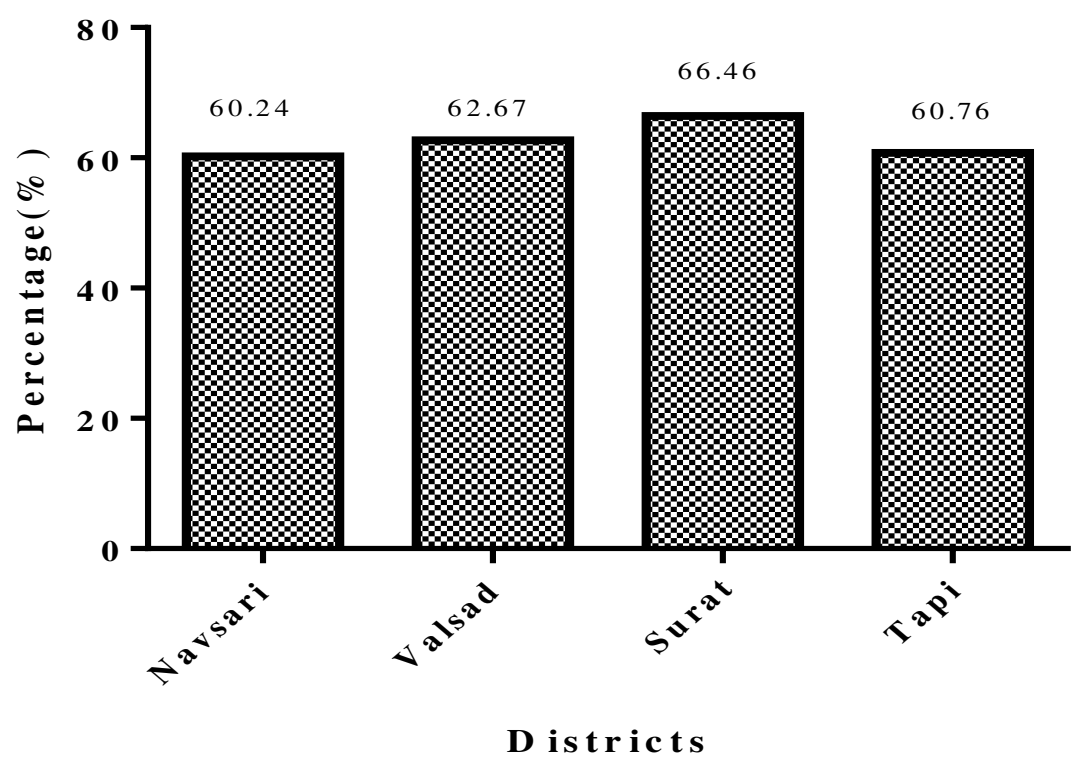

Fig.3 Species, sex and age wise seroprevalence of PPR

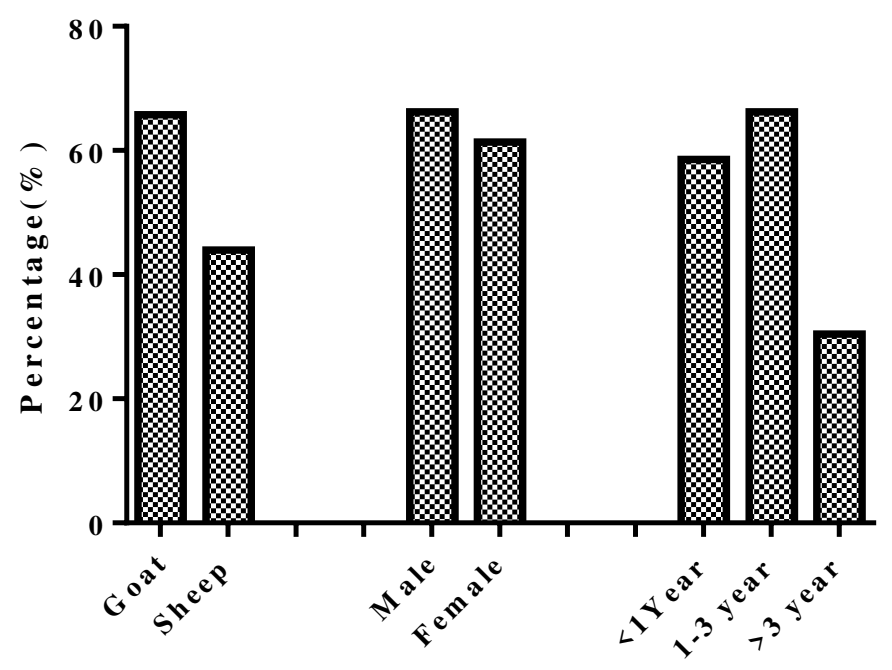

Species, Sex and Agew ise 
Fig.4 Month wise seroprevalence of PPR

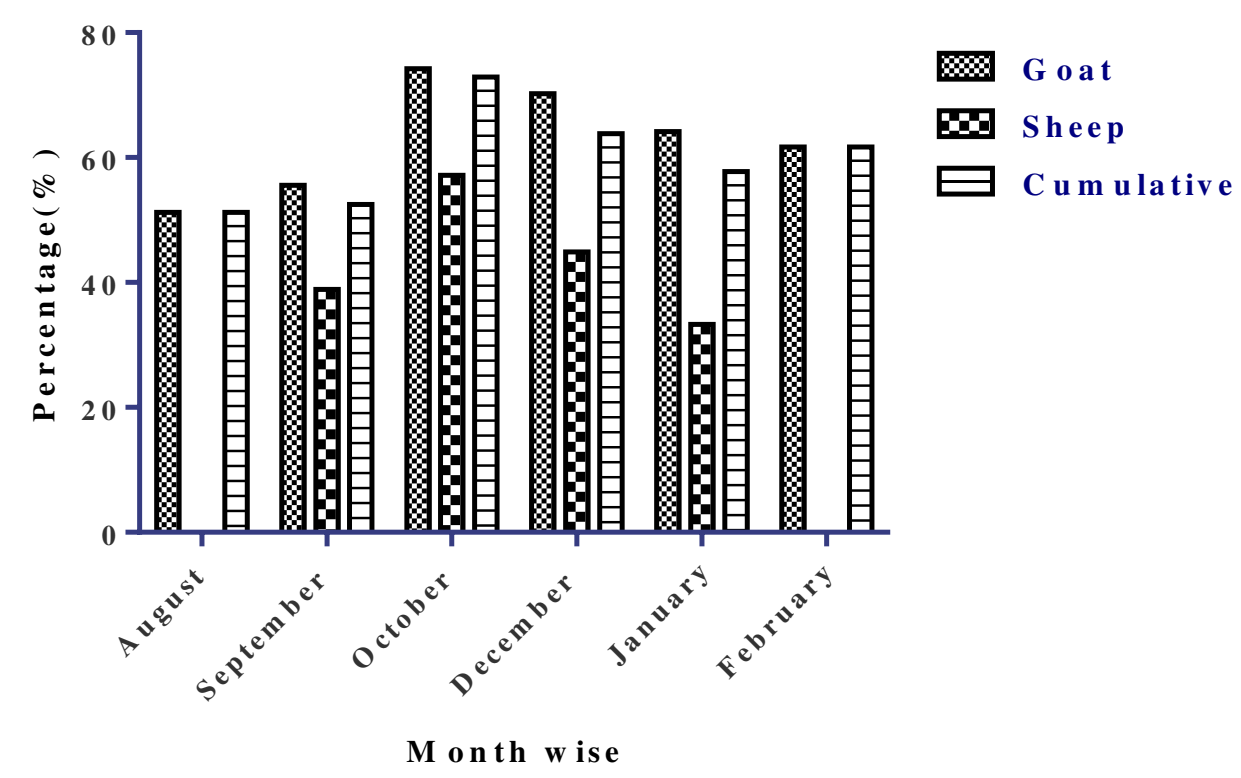

Fig.5 Frequency distribution of confirm positive samples

Frequency distribution data (2015-17)

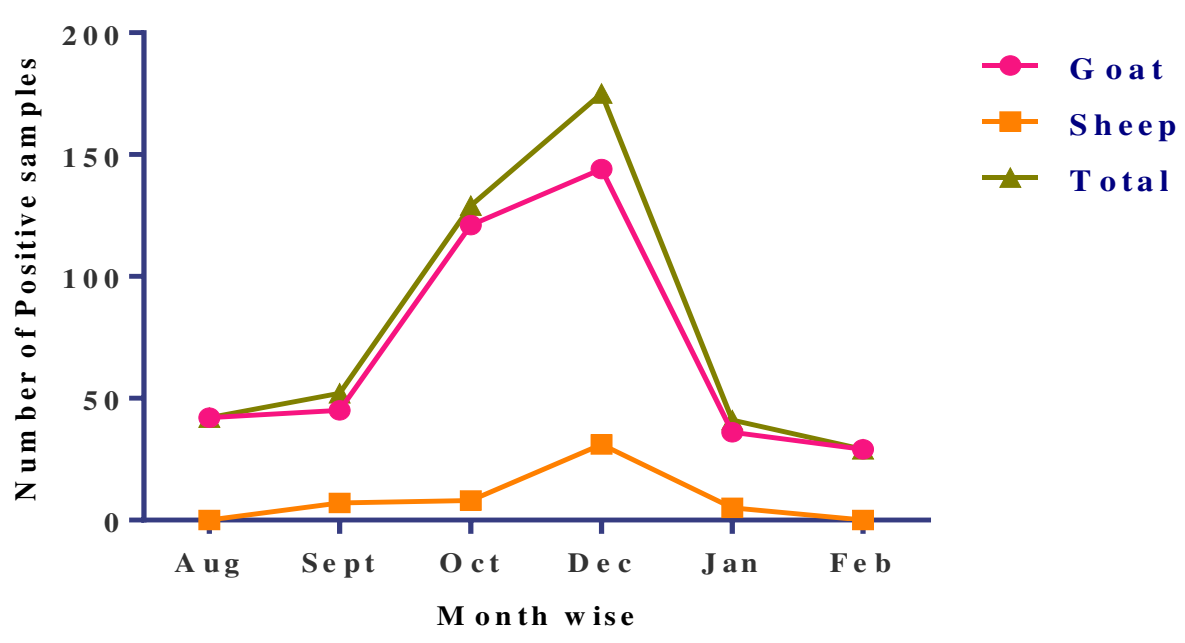

However, the higher seroprevalence in young ones was opined in South Gujarat (Thakor et al., 2016; Patel et al., 2017). Higher seroprevalence rate in above 6 months of age than below 6 months was also reported (Begum et al., 2016; De et al., 2016). The factual explanation of the present findings has been justified by the fact that sheep and goats exposed to natural infection to PPRV at a very young age may carry antibodies for 1-2 year following exposure and might be carried for life long time (Devi et al., 2016; Kahn, 2010).

Maximum seroprevalence $(70.63 \%)$ was found in goats of 1-3 years of age followed by the age group of $<1$ year $(60.92 \%)$ and $>3$ 
years $(27.77 \%)$. The age wise prevalence was found as significantly different among groups which supports the earlier findings of (Chauhan et al., 2011; Nizamani et al., 2015). On the contrary, higher seropositivity was observed in below 6 months age (Thakor et $a l ., 2016)$ and less 1 year of age, (Patel et al., 2017) respectively. When sheep sera were tested as per same age grouping maximum seroprevalence $(45.67 \%)$ was found in animals above 1-3 years of age, than the age group of $<1$ year $(40 \%)$ and $>3$ years $(40 \%)$. Unlike goat, the age wise prevalence was not differing significantly among groups. The per cent positivity was in accordance of the published reports (Nizamani et al., 2015; Rahman et al., 2017). However, highest incidence of PPR was recorded in $<1$ year and $>3$ years of age (Mahajan et al., 2012). The seroprevalence rate found in sheep was $41.12 \%$ (Ranaware et al., 2013) in Gandhinagar region of Gujarat. None of the previous study for seroprevalence in sheep has been found for Valsad and Tapi districts of south Gujarat.

Month wise seroprevalence of PPR was found in accordance of (Abubakar et al., 2009) where two different seasonal variations were found. Our study has shown highest positivity during the September to January duration. This duration is immediately after raining season and starting of winter in India. During which temperature and humidity fluctuation makes favorable condition to PPRV for infection in animals. Environmental changes also make putative impact on animal health which tends to compromised immunity of host. Balamurugan et al., (2012) have also found month wise distribution of the percent positivity of samples. They have similarly reported majorly positivity during august to October time. Taylor, 1984 reported that PPR incidence majorly observed in winter season whereas Wosu, 1994noted that dry season is most favorable for the disease occurrence.
Overall dry and cold weather combination during the October to February favors the spread of disease (Balamurugan et al., 2012).

Thus the present study revealed the valuable sufficient data on the seroepidemiology of PPRV in sheep, goats and its cofactor with age, sex, region and seasonal variations in southern districts of Gujarat which may help in policy making on vaccination and preventive strategy for the control of disease. Regular time to time vaccination is strongly required in young and adult small ruminants. Our study has clearly given the basic idea for the point of vaccination time, care and preventive preparedness before the outbreak.

\section{Acknowledgments}

The authors thankfully acknowledge to the Dean, College of veterinary science and animal husbandry, Navsari Agricultural University, Navsari for providing funds with necessary facilities to conduct this study under the Department of Veterinary Microbiology.

\section{References}

Abubakar, M., Jamal, S. M., Arshed, M. J., Hussain, M., and Ali, Q. 2009. Peste des petits ruminants virus (PPRV) infection; its association with species, seasonal variations and geography. Tropical animal health and production, 41(7): 1197.

Afera B, Hussien D Amsalu K. 2014. Seroprevalence of Peste Des Petits Ruminants in Goats of Southern Parts of Tigray Region. Global Veterinaria, 12(4): 512-516.

Anderson EC, Hassan A, Barrett T, Anderson J. 1990. Observation on the pathogenicity for sheep and goat and the transmissibility of the strain of virus isolated during the rinderpest outbreak in Srilanka in 1987. Vet Microbiol. 21: 309-318. 
BalamuruganV, Saravanan P, Sen A, Rajak KK, Bhanuprakash V, Krishnamoorthy P, Singh RK. 2011. Sero-epidemiological study of pestedes petitsruminants in sheep and goats in India between2003and 2009. Rev Sci Tech. 30(3): 889-896.

Balamurugan V, Sen A, Venkatesan G, Yadav V, Bhanuprakash V, Singh R K. 2010. Isolation and identification of virulent peste des petits ruminants viruses from PPR outbreaks in India. Trop Anim Health Prod. 42(6): 1043-6.

Balamurugan, V., Saravanan, P., Sen, A., Rajak, K.K., Venkatesan, G., Krishnamoorthy, P., Bhanuprakash, V. and Singh, R.K. 2012. Prevalence of peste des petits ruminants among sheep and goats in India. Journal of veterinary science, 13(3): 279-285.

Begum SS, Mahato G, Sharma P, Sharma K, Hussain M, Das BC, Hussain J, De A, Choudhary D, Ramkrishnan AM, Muthuchelvan D. 2016. Seroprevalence of Peste des petits ruminants in goats in Assam India. Asian $\mathrm{j}$ Anim and Vet Adv.11: 210-212.

Chandrahas S, ChandelBS, ChauhanHC, Dadawala AI. 2011. Seroprevalence of PPR in sheep and goats of North Gujarat. Ind J Small Rumi. 17(1): 118121.

Chauhan H, Dadawala A, Chandel B, Kalyani I, Patel S, Kher H.2012. Seroprevalence of peste des petits ruminants in small ruminants under different managemental conditions. Ind J Field Vet.; 7(3): 37-39.

Chauhan HC, Lambade PS, Sen A, Dadawala AI, Ranaware PB, Chandel B, Jhoshi DV, Patel SS, Kumar P, Shah NM, Kher HN. 2011. The use of pathological and histopathological techniques in the diagnosis of peste des petits ruminatnts in India. Veterinarian Italiana. 47(1): 4147.

Couacy-Hymann E, Bidjesh K, Angba A, Domenech J, Diallo A. 1995. Protection of goats against rinderpest by vaccination with attenuated peste des petits ruminants virus. ResVetSci. 59:106-109.

De A, Debnath B, Dutta TK, Shil S, Bhadouriya S, Chaudhary D, Rajak KK, Pachauri R, Ramakrishnan MA, Muthuchelvan D. 2016. Sero-epidemiology of peste-despetits-ruminants in goats of Tripura state of North-East India. Adv in Anim and VetSci. 4(5): 215-217.

Devi Maitrayee, Das Sutopa, Sharma Krishna, Dutt Rupam.2016. Seroprevelance and molecular detection of peste des petits ruminants in goats of Assam. Virus Dis.; 27(1): 91-97.

Dhar P, Sreenivasa BP, Barrett T, Corteyn M, Singh RP, Bandyopadhyay SK. 2002. Recent epidemiology of peste des petits ruminants virus (PPRV). Vet Microbiol. 88(2): 153-159.

FAO. 2009. Peste des petits ruminants: an increasing threat to small ruminant production in Africa and Asia. EMPRES Transboundary Animal Disease Bullettin. No. 33

Gibbs EPJ, TaylorWP, Lawman MJP and Bryant J. 1979. Classification of peste des petits ruminants virus as the fourth member of the genus Morbillivirus. Inter Virol. 11: 268-274.

Hinshu TV, Kher HN, Chandel BS, Jhala MK. Seroprevalence of Peste des petits ruminants (PPR) in Gujarat.2001. Indian J Comp Microbiol Immunol Infect. Dis.22 (1):81.

Kahn CM.2010. Themerck veterinary manual 10th edn White House Station Merck \& CoInc New Jersey Pp 617.

KananiA,Sutariya P, Shukla R, ShuklaR.2006. Seroprevalence of Pestedes petits ruminants (PPR) in small ruminants of Gujarat State. Indian J Field Veterinarians. 1(4): 22- 23.

Karelewad VS, Bhikane AU, Ambore B N, Awaz KB.2007. Epidemiological Observation on Peste Des Petits Ruminatsin Osamb and iGoats in Maharashtra. Vet Pract. 8(1): 92-93.

Kataria AK, Kataria N, Gahlot AK. 2007. Large scale outbreak of peste des petits 
ruminants virus in sheep and goats in Thar desert of India. Slovenian Vet Res. 44: 123-132.

Kerur N, Jhala MK, Joshi CG.2008. Genetic characterization of Indian peste des petits ruminants virus (PPRV) by sequencing and phylogenetic analysis of fusion protein and nucleoprotein gene segments. Res in Vet Sci. 85: 176-183.

Khan HA, Siddique M, Arshad MJ, Khan QM, Rehman SU. 2007. Sero-prevalence of peste des petits ruminants (PPR) virus in sheep and goats in Punjab province of Pakistan. Pak Vet J.3 (27): 109-112.

Krishna SV, Subharao MV, Shaila MS.2001. Neutralizing antibodies to peste des petits ruminants virus in small ruminants in Andhra Pradesh - a serological survey. Indian J Anim Sci. 71: 228-230.

Kumar Naveen, Maherchandani Sunil, Kashyap Sudhir Kumar, Singh Shoor Vir, Sharma Shalini, Chaubey Kundan Kumar, Ly Hinh. 2014. Peste Des Petits Ruminants Virus Infection of Small Ruminants: A Comprehensive Review. Viruses.6: 2287-2327.

Lefevre PC, Diallo A. 1990. Peste des petits ruminants Revue Scientifique et Technique de 1' Office International des Epizooties. 9(4): 951-65.

Libeau G, Prehaud C, Lancelot R, Colas F, Guerre L, Bishop DHL, Diallo A.1995. Development of a competitive ELISA for detecting antibodies to the peste des petits ruminants virus usinga recombinant nucleoprotein. Res Vet Sci. $58: 50-5$.

Mahajan S, Agrawal R, Kumar M, Mohan A and Pande N. 2012. Risk of seroconversion to peste des petits ruminants (PPR) and its association with species sex age and migration. Small Rumi Res. 104(1): 195200

Nagraj. 2006. Assessment of different gene target for detection of Peste despetits ruminants by RT-PCR and Sequence analysis of $\mathrm{F}$ and $\mathrm{N}$ gene segments MVSc thesis submitted to Anand
Agricultural University Anand, India; Pp:124

Nizamani AR, Nizamani ZA, Umrani AP, Dewani P, Vandiar MA, Gandhi JA Soomro NM. 2015. Prevalence of Peste des Petits Ruminants viruses antibodies in small ruminants of Pakistan. The $\mathrm{J}$ Ani \& Plant Sci. 25(6): 1515-1519.

OIE.2013. Peste des petits ruminants In: Manual of diagnostic tests and vaccines for terrestrial animals 7th Edition Chapter 2711 Office International des Epizooties (OIE) Paris.

Patel Yash R, Patel Jignesh M, Vihol Priti D, Kalyani IH, Sakhare Pramod S, Panchal Pratik P, Thakor Kaushik D.2017. Seroprevalence of Peste des Petits Ruminants (PPR) in Navsari and Valsad Districts of South Gujarat. Int J Curr Microbiol App Sci.6(8): 221-228.

Raghavendra A G, Gajendragad M R, Sengupta $\mathrm{P}$ P, Patil S S, Tiwari C B, Balumahendiran $\mathrm{M}$, Sankri $\mathrm{V}$ and Prabhudas K. 2008. Seroepidemiology of peste des petits ruminants in sheep and goats of southern peninsular India. Scientific and Technical Review of the Office International des Epizooties. 27: 861-867.

Rahman A, Yousaf F, Anwar N and Abubakar M. 2017. Serological detection of peste des petits ruminants virus (PPRV) in sheep and goats of Muzaffargarh district in South Punjab Pakistan. Veterinary Sciences: Res and Rev.2(3): 82-88.

Ranaware BP, Chauhan HC, Shah NM, Chandel BS, Pankaj Kumar Dadawala AI, Patel SS, Parekar SS.2013. Seroepidemiology of Peste Des Petits Ruminants (PPR) in Small Ruminants in Gujarat. Indian Vet J.90 (4):9 -10.

Saha A, Lodh C, Chakraborty A.2005. Prevalence of PPR in goats. Indian Vet J. 82: 668-669.

Santhosh A, Raveendra H,Isloor S,GomesR, Rathnamma D, ByregowdaS, Prabhudas K, Renikprasad C. 2009. Seroprevalence of PPR in organised and unorganised 
sectors in Karnataka. Indian Vet J. 86: 659- 660.

Shaila MS, Purushothaman V, Bhavasar D, Venugopal K, Venkatesan RA. 1989. Peste des petits ruminants of sheep in India. Vet Rec. 125:502.

Sharma KK, Kshirsagar D, Kalyani I, Patel D, Vihol P, Patel J. 2015. Diagnosis of peste despetits ruminants infection in small ruminants through in- house developed Indirect ELISA: Practical considerations. Vet World. 8(4):443448.

Singh B, Bardhan D, Verma MR, Prasad S and Sinha DK. 2014. Estimation of economic losses due to Pestede Petits Ruminants in small ruminants in India. Vet World. 7(4):194-199.

Singh RP, Saravanan P, Sreenivasa BP, Singh RK, Bandyopadhyay SK. 2004a. Prevalence and distribution of peste des petits ruminants (PPR) virus infection in small ruminants of India. Scientific and Technical Review of the Office International des Epizooties.23 (3): 807819.

Singh RP, Sreenivasa BP, Dhar P Shah LC, Bandyopadhyay SK. 2004b. Development of a monoclonal antibody based competitive- ELISA for detection and titration of antibodies to peste des petits ruminants (PPR) virus. Vet Microbiol. 98: 3-15.

Tariq A, Aqil K, Akabaar Z, Mahboob K, Sarfraz A, Rafique R, Nasir F, Parveen S. 2014. Peste despetits ruminant (PPR) in small Ruminants- A clinical hematoserologicalandpathologicalaspects.InterJ VetSci.;3(4): 206-209.

Taylor WP. 1984. The distribution and epidemiology of peste des petits ruminants. Prev Vet Med, 2, 157-166.

Thakor RB, Patel MD, Patel RM, Kalyani IH. 2016. Seroprevalence ofpeste des petits ruminants in goats of south Gujarat. Indian J small ruminants. 22(2): 252254.

Tiwari A. 2004. Prevalence of Peste-des petits ruminants (PPR) virus in small ruminants of Gujarat and its characterization by RT-PCR/RFLP and SSCP profiles MVSc Thesis submitted to Anand Agricultural University Anand, India,.

Wang Z, Bao J, Wu X, Liu Y, Li L, Liu C, Suo L, Xie Z, Zhao W.2009. Peste des petits ruminants virus in Tibet China. Emerg Infect Dis.15: 299-301.

Wosu LO.1994. Current status of peste des petits ruminants (PPR) disease in small ruminants: a review article. Stud Res Vet Med, 2, 83-90

\section{How to cite this article:}

Pramod Sakhare, Irshadullahkhan Kalyani, Priti Vihol, Kishan Sharma, Jayesh Solanki, Dhruv Desai and Pushpa Makwana. 2019. Seroepidemiology of Peste Des Petits Ruminants (PPR) in Sheep and Goats of Southern Districts of Gujarat, India. Int.J.Curr.Microbiol.App.Sci. 8(11): 15521565. doi: https://doi.org/10.20546/ijcmas.2019.811.180 